\title{
Performance of cover and corn plants in different mechanical and biological management associations
}

\author{
Jhonatan Spliethoff ${ }^{1} \oplus$, Leandro Rampim ${ }^{1} \oplus$, Cristiano Andre Pott ${ }^{1} \oplus$ \\ 1 Universidade Estadual do Centro-Oeste do Paraná, Departamento de Agronomia, Guarapuava-PR, Brasil. E-mail: jhonatanspliethoff@hotmail.com; rampimleandro@hotmail.com; \\ cpott@unicentro.br
}

ABSTRACT: Countless cases of the no-tillage system in compacted layers are seen, making the adoption of management practices that improve the soil physical quality necessary. In this context, this study aimed to verify the influence of mechanical and biological management on the morphophysiological characters and yield of the corn crop and dry matter of cover crops cultivated in an Oxisol. The experiment was conducted at FAZESC, Farm School of the State University of the Central West - UNICENTRO, Guarapuava-PR, in an Oxisol with a very clayey texture. The used experimental design was of completely randomized blocks with split-split plots, with the following evaluated factors: with or without scarification in the plots, sowing with double disc or seed boot in the subplots and soil cover crops (black oat succeeded by the mixture composed by black oat, forage turnip, blue lupine, rye and common vetch; turnip succeeded by the consortium black oat + forage turnip; and fallow) in the sub-subplots. Dry matter production of soil covers, as well as morphophysiological attributes and corn crop yield were evaluated. Soil scarification did not affect corn yield, regardless of the used soil cover or furrowing system at sowing. Seeding done with seed boot limited the corn yield when associated to the soil cover with black oat and soil management with scarification. Soil cover has an effect on the stability and yield of the corn crop, with the fallow being the most productive instability. The mixture of toppings and the black oat + forage turnip had a high potential of dry matter production.

Key words: soil compaction; soil management; yield

\section{Desempenho de plantas de cobertura e milho em diferentes associações} de manejo mecânico e biológico

RESUMO: Observam-se inúmeros casos de sistema de semeadura direta com camadas compactadas, tornando-se necessária a adoção de práticas de manejo que melhoram a qualidade física do solo. Nesse contexto, o objetivo deste trabalho foi verificar a influência do manejo mecânico e biológico nos caracteres morfofisiológicos e na produtividade da cultura de milho e matéria seca de plantas de cobertura cultivadas em Latossolo Bruno. $O$ experimento foi conduzido na FAZESC, Fazenda Escola da Universidade Estadual do Centro Oeste - UNICENTRO, Guarapuava - PR, em Latossolo Bruno, de textura muito argilosa. 0 delineamento experimental utilizado foi em blocos casualizados, com parcelas sub-subdivididas, sendo os fatores avaliados: com ou sem escarificação nas parcelas, semeadura com disco duplo ou haste sulcadora nas subparcelas e cobertura do solo (aveia preta sucedida pelo Mix de coberturas composto por aveia preta, nabo forrageiro, tremoço azul, centeio e ervilhaca comum; nabo forrageiro sucedido pelo consórcio aveia preta + nabo forrageiro; e pousio) nas sub-subparcelas. Foram avaliados a produção de matéria seca das coberturas de solo, bem como os atributos morfofisiológicos e produtividade da cultura do milho. A escarificação do solo não afetou a produtividade do milho, independente da utilização de cobertura de solo ou sistema sulcador na semeadura. Semeadura com haste sulcadora limitou a produtividade do milho quando associado à cobertura do solo com aveia preta e manejo de solo com escarificação. A cobertura do solo tem efeito na estabilidade e produtividade da cultura do milho, tendo o pousio a maior instabilidade produtiva. 0 mix de coberturas e o consórcio aveia preta + nabo forrageiro apresentaram alto potencial de produção de matéria seca.

Palavras-chave: compactação do solo; manejo do solo; produtividade 


\section{Introduction}

Brazil produced approximately 230 million tons of grains in 2018 (Conab, 2018), reaching the top places in the world grain production ranking, which is logically influenced by the size of the arable land in the country, favorable climate and mainly, management technologies employed. Among the already established management technologies, the no-tillage system (NTS) stands out.

The NTS, adopted in the early 1970s, is responsible for the Brazilian leadership in grains production and export. This system favors the agricultural environment in such a significant way that, currently, 32 million hectares are cultivated under no-tillage (Febrapd, 2018). However, even so, due to the lack of soil revolving, inadequate use and management associated with traffic intensity, it is observed the formation of compacted layers in this system (Franchini et al., 2012).

Soil compaction tends to cause numerous physical changes within it, such as increased density and penetration resistance, reduced total porosity, macroporosity, and water storage (Dal Ferro et al., 2014; McPhee et al., 2015; Moraes et al., 2016). Such factors directly affect root growth and yield of crops like corn and soybean (Drescher et al., 2012; Oliveira et al., 2012; Kormanek et al., 2015; Botta et al., 2016; Grzesiak et al., 2016; Espessato et al., 2017).

Scarification provides disruption of compacted layers and soil breakdown, creating macropores and improving soil permeability that facilitate root growth and corrective movement in the soil (Prado et al., 2014; Guedes Filho et al., 2015). Another mechanical alternative is the use of seed boots on the seeder, which can improve the soil physical characteristics, such as reduced density and increased porosity in the sowing furrow, thus promoting yield gains in crops such as corn and soybean (Giacomeli et al., 2016; Drescher et al., 2017; Trentin et al., 2018). Green manures, in addition to improving the soil physical condition, have improved their protection against weather conditions, also recycling nutrients and reducing fertilizer expenses (Fageria, 2014; Nascente et al., 2016).

Cover crops use provides numerous benefits to the soil and, consequently, the plants of economic interest. Regarding chemical quality, Borkert et al. (2003) found that cover crops are essential for maintaining soil sustainability as they are nutrient recyclers. The same authors point out the potential of species such as black oat and vetch in recycling potassium, lupine and vetch to accumulate nitrogen and being, in addition to that, satisfactory micronutrient accumulators. Calegari et al. (2013) demonstrated, in a long-term study with different management systems, that both black oat and lupine are efficient in recycling phosphorus and increasing the available $P$ in the soil, and they have also shown that keeping fallow during winter results in lower availability of $P$ and $\mathrm{K}$, highlighting the cover crops importance in this period. Concerning the soil physical quality, Silva et al. (2019), when studying the effects of different management systems on the structural quality of dystrophic red Ultisol, found that the use of covers such as black oat + vetch increased aggregate stability. In Dystroferric Red Oxisol, studies show the potential of black oat in reducing soil density (Santos et al., 2015). Regarding the effect of cover plants on the economic interest ones, Lima et al. (2012a), observed that when using a cover cocktail (black oat, forage turnip and common vetch) the emergence speed index of soybean seedlings was higher, providing more vigorous seedlings. With better-performing seedlings, the yield may benefit, as reported by Krenchinski et al. (2018), which showed an increase in soybean (Glycine max) production when using cover cropping, pointing out the potential of the black oat and the forage turnip.

Thus, the objective of this study was to evaluate the influence of mechanical and biological management on morphophysiological traits and corn crop yield and the dry matter of cover crops cultivated in Oxisol.

\section{Materials and Methods}

\section{Localization, experimental design and management}

The experiment was conducted at FAZESC, Farm School of the State University of the Central West - UNICENTRO, Guarapuava-PR, in an area under direct seeding whose geographical coordinates are 2523'07" S e 513' $16^{\prime \prime}$ 'W, with an altitude of $1,006 \mathrm{~m}$. The experiment was carried out in the field from June 2017 to October 2018, in a no-tillage system in a soil classified as Oxisol (Santos et al., 2018), with a very clayey texture ( $850 \mathrm{~g} \mathrm{~kg}^{-1}$ of clay in the $0.0-0.2 \mathrm{~m}$ soil layer).

The region climate is classified as $\mathrm{Cfb}$ (humid mesothermal subtropical), with no defined dry season, having cool summers and winters with often and severe frosts, according to the Köppen classification (Alvares et al., 2013). The mean precipitation of the area is $1800 \mathrm{~mm}$ per year (Figure 1).

A randomized blocks experimental design was used, with sub-subdivided plots, with four replicates, totaling 48 experimental units. Each experimental sub-subplot was 16.5 $\mathrm{m}$ in length $\times 4 \mathrm{~m}$ in width, totaling $66 \mathrm{~m}^{2}$. The evaluated factors were scarification (area with or without scarification) in the plots, associated to the furrowing mechanism in corn sowing (double disc or seed boot) in the subplots and soil cover (forage turnip, black oat, fallow) in the sub-subplots. Evaluations were performed in two moments, the first one at 120 days after scarification and the second one at 360 days after scarification. It is worth mentioning that the first moment was evaluated as subdivided plots since the furrower mechanism had not been set up yet. In the other moments, the three factors were taken into account.

Initially the experimental area was sampled to characterize the chemical (described in the next paragraph) and the physical attributes (Table 1). Based on the results obtained in the characterization, it was found that the area presented physical restrictions, since the aeration pores (macropores) were below $10 \mathrm{~m}^{-3} \mathrm{~m}^{-3}$ in the 0.1-0.2 m layer, an indicative of compaction problems and plant growth limitation (Reichert et al., 2009). 


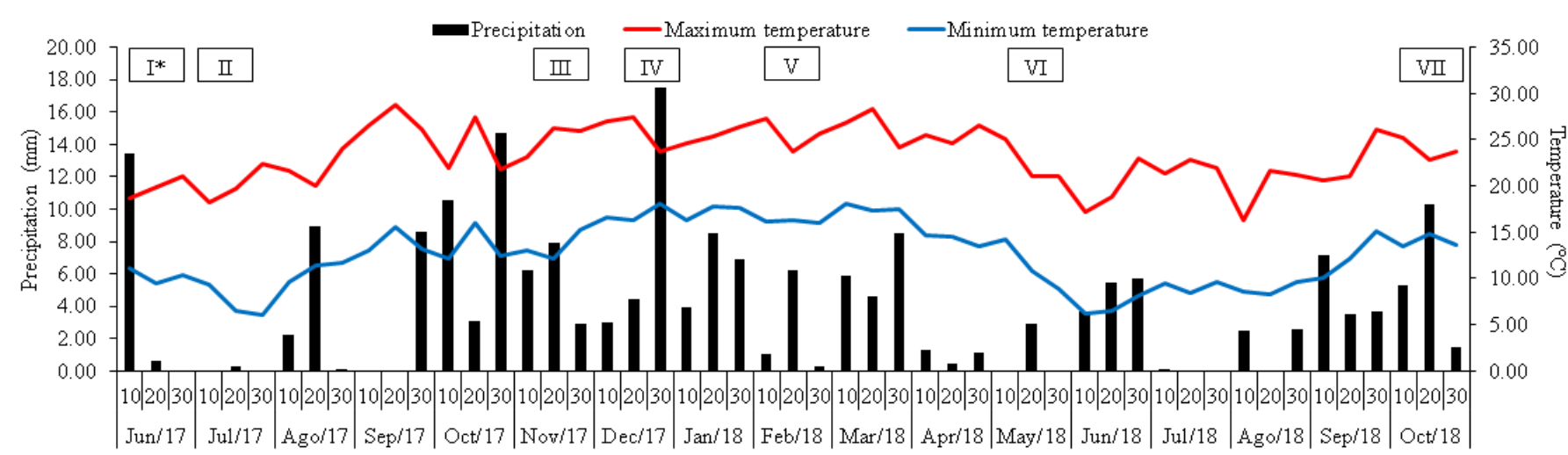

Figure 1. Precipitation, maximum temperature, minimum temperature (10-day mean) and experiment timeline from June 2017 to October 2018. *Timeline: (I) Initial characterization of the area; (II) Scarification and sowing of cover crops; (III) Evaluation of cover crops and soil physical attributes; (IV) Sowing of corn crop; (VI) Corn harvest, evaluation of soil physical attributes and sowing of cover crops; (VII) evaluation of cover crops and soil physical attributes.

In July 2017, scarification was performed with Asa Laser $\mathrm{KS}^{\circ}$ powered by a John Deere 7195 tractor. The equipment had nine seed boots, spaced $0.6 \mathrm{~m}$ apart each other, with a soil destroyer coupled to it.

The analysis of the soil chemical attributes was held in the 0.0-0.2 $\mathrm{m}$ layer with the following results: $\mathrm{P}=6.93 \mathrm{~g} \mathrm{dm}^{-3} ; \mathrm{OM}$ $=29.04 \mathrm{~g} \mathrm{dm}^{-3} ; \mathrm{pH}\left(\mathrm{CaCl}_{2}\right)=4.73 ; \mathrm{K}^{+}=0.19 \mathrm{cmol}_{\mathrm{c}} \mathrm{dm}^{-3} ; \mathrm{Ca}^{2+}=$ $2.86 \mathrm{cmol}_{\mathrm{c}} \mathrm{dm}^{-3} ; \mathrm{Mg}^{2+}=1.25 \mathrm{cmol}_{\mathrm{c}} \mathrm{dm}^{-3} ; \mathrm{H}+\mathrm{Al}=4.59 \mathrm{cmol}_{\mathrm{c}}$ $\mathrm{dm}^{-3} ; \mathrm{Al}^{3+}=0.21 \mathrm{cmol}_{\mathrm{c}} \mathrm{dm}^{-3}$ and sum of bases $(\mathrm{SB})=4.31 \mathrm{cmol}_{\mathrm{c}}$ $\mathrm{dm}^{-3}$. It is noteworthy that, although the soil chemical analysis required liming, it was not performed as it could interfere with the crop yield response in areas with and without scarification, by limestone movement along the soil profile.

Three days after scarification, the green manures were sown, at the same time, as the desiccation of the fallow areas occurred to keep them weed free. Sowing of cover crops was performed with a Kuhn ${ }^{\circ}$ model SDM Select 2215/17 seeder, powered by a New Holland ${ }^{\circ}$ TL95 tractor. For forage turnip cultivation, $20 \mathrm{~kg} \mathrm{ha}^{-1}$ of seeds from the Trado cultivar (developed by FAPA) were used; and for black oat, $70 \mathrm{~kg} \mathrm{ha}^{-1}$ of seeds from lapar 61 cultivar were used.

In the summer period, after desiccation of the experimental area, the corn crop was implanted 150 days after the scarification (12/13/2017), with density of 90,000 plants per hectare. The used hybrid was the P3456 $\mathrm{VYH}^{\circ}$, characterized as a super-early high-yield hybrid. $400 \mathrm{~kg} \mathrm{ha}^{-1}$ of formulated $08-30-20$ fertilizer and $800 \mathrm{~kg} \mathrm{ha}^{-1}$ of urea $(45 \%$ nitrogen source) were applied at the sowing, having been divided into two applications. Phytosanitary management of the crop was based on technical recommendations proposed by Embrapa (2017).
After corn harvest, the sub-subplots with forage turnip were replaced by the treatment black oat + forage turnip $(\mathrm{A}+\mathrm{N})$, using $40 \mathrm{~kg} \mathrm{ha}^{-1}$ of black oat (lapar 61 crops) and $15 \mathrm{~kg}$ $\mathrm{ha}^{-1}$ of forage turnip (IPR 116 cultivar). The sub-subplots with black oats were then replaced by the covers mix, composed of $15 \mathrm{~kg} \mathrm{ha}^{-1}$ of black oat (lapar 61 cultivar), $8 \mathrm{~kg} \mathrm{ha}^{-1}$ of forage turnip (IPR 116 cultivar), $25 \mathrm{~kg} \mathrm{ha}^{-1}$ blue lupine (lapar 24), 20 $\mathrm{kg} \mathrm{ha}^{-1}$ of common vetch, and $15 \mathrm{~kg} \mathrm{ha}^{-1}$ of rye (IPR 89 cultivar). The fallow subplots continued the same treatment.

\section{Green manure production parameters}

After 120 days of implantation, the dry matter production of green manure black oat and forage turnip were evaluated. Sampling was held at two points per plot, totaling an area of $0.5 \mathrm{~m}^{2}$. The samples were dried at $105^{\circ} \mathrm{C}$ and later their values were extrapolated to hectare. In the fallow plots there was weed growth, but their chemical and physical control were carried out and, thus, there was no dry matter production. At this time of the evaluation, there was no sowing system factor, being considered a subdivided plot, with scarification (area with or without scarification) in the plots, associated with soil cover (turnip, oat, fallow) in the subplots, totaling 24 E.U (Experimental Units).

At 480 days after scarification and implementation of new treatments for soil covering, an area of $1 \mathrm{~m}^{2}$ per experimental plot was collected. In the fallow areas, weed dry matter collection was held. Samples were dried at $105 \stackrel{\circ}{\circ}$ and then their values were extrapolated for the hectare.

\section{Morphophysiological parameters and corn crop yield}

In order to evaluate the morphophysiological traits of corn plants, ten plants were considered per E.U. In these

Table 1. Initial characterization of soil physical attributes from the study area in an Oxisol. Guarapuava/PR, 2017.

\begin{tabular}{lcccc}
\hline \multicolumn{1}{c}{ Attribute } & & $\mathbf{0 . 0 7 - 0 . 1 2} \mathbf{~ m}$ & $\mathbf{0 . 1 7 - 0 . 2 2} \mathbf{m}$ & $\mathbf{0 . 2 6 - 0 . 4 0 ~} \mathbf{m}$ \\
\hline Penetration resistance & $\mathrm{kPa}$ & 908.20 & 2337.90 & 1580.90 \\
Soil density & $\mathrm{Mg} \mathrm{m}^{-3}$ & 1.12 & 1.30 & - \\
Macroporosity & $\mathrm{m}^{3} \mathrm{~m}^{-3}$ & 0.19 & 0.09 & - \\
Microporosity & $\mathrm{m}^{3} \mathrm{~m}^{-3}$ & 0.42 & 0.48 & - \\
Total Porosity & $\mathrm{m}^{3} \mathrm{~m}^{-3}$ & 0.61 & 0.56 \\
\hline
\end{tabular}


plants, total chlorophyll content (chlorophyll a and b) was quantified with a Falker equipment model chlorofiLOG 1030, measuring in the middle-third of the flag leaf. Plant height $(\mathrm{PH})$, ear insertion height $(\mathrm{EIH})$ and stem diameter (SD) were also measured during flowering. After harvesting, ear length $(E L)$, number of rows per ear (NR), number of grains per row (NGR) and ear diameter (ED) of ten ears per plot were determined. Spikes harvested in a useful area of $28 \mathrm{~m}^{2}$ per plot were traced, classified and the grain weight corrected to $13 \%$ moisture in order to determine the weight of 1000 grains (W1000), according to the Brazilian rules for seed analysis (Regras para Análise de Sementes, Brazil, 2009) and the grain yield was extrapolated to hectares.

\section{Statistical analysis}

Data were subjected to analysis of variance with $5 \%$ probability of error. When identified the significant effect, comparison of means was performed by Tukey test at $5 \%$ probability of error.

\section{Results and Discussion}

\section{First cover crops and summer crop (corn)}

Management did not affect the dry matter production of the coverings (Table 2). It is worth noticing that in the fallow plots there was no dry matter production, since there was no vegetal production in these plots due to chemical and physical

Table 2. Result of analysis of variance ( $F$ values) and mean dry matter for soil cover ( $\left.\mathrm{kg} \mathrm{ha}^{-1}\right)$ in an Oxisol. Guarapuava-PR, 2019.

\begin{tabular}{cc}
\hline VS & Dry matter \\
\hline & F Values \\
\hline Scarification & 0.671 \\
Cover & 3.23 \\
Cover*Scarification & 0.08 \\
CV Scarification (\%) & 22.81 \\
CV Cover (\%) & 20.57 \\
\hline & General mean \\
\hline
\end{tabular}

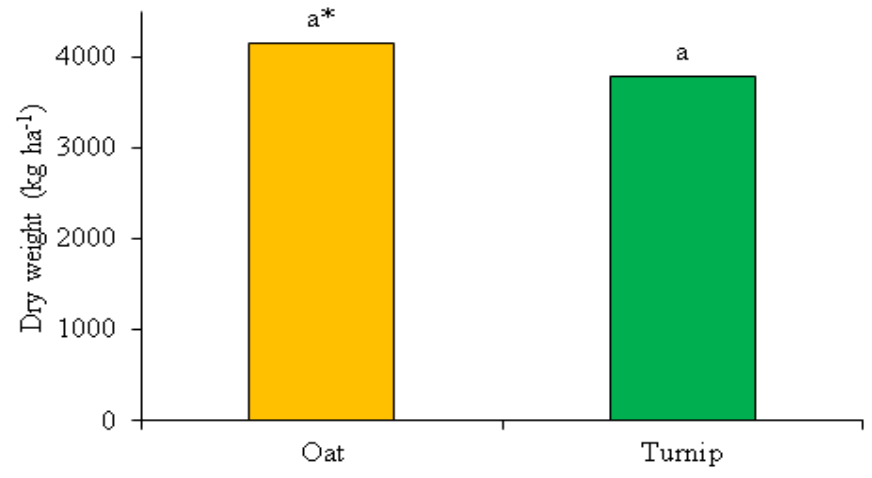

*Means followed by the same letter do not differ by $\mathrm{F}$ test $(p \geq 0.05)$.

Figure 2. Dry matter production of different soil cover in an Oxisol.

weed management. Thus, oat and turnip treatments were significantly higher, but their dry matter yields did not differ from each other (Figure 2). Different results were found by Valicheski et al. (2012), who observed that oat dry matter production was almost the double of the turnip production, indifferent of the compaction level of the silt-loam soil, reaching approximately $4,000 \mathrm{~kg}$ of dry matter per hectare. Ziech et al. (2015) pointed out the high potential of grasses such as oats in maintaining stubble, since this crop has a high yield of dry matter, giving a input of it of over 2,600 kg ha-1 after 49 days, when cultivated in Red Oxisol under subtropical climate without a defined dry season ( $\mathrm{Cfa}$ ). The same authors report a mean turnip production (in two years) of more than $2,400 \mathrm{~kg} \mathrm{ha}^{-1}$, a value much lower than the obtained in this study. Dry matter yields achieved in the present study show the potential of both species as green manures, which in addition of increasing the soil organic matter content, can improve the soil fertility aspects (Rosa et al., 2017).

Total chlorophyll content in corn crop flowering was significant by the $\mathrm{F}$ test (Table 3 ), presenting mean values of 519.5 for scarified areas and 549.8 for areas without scarification (Figure 3). It is noteworthy that total chlorophyll is given by the sum of the contents from chlorophyll $a+b$, and that the chlorophyll a/b ratio remained similar, even with

Table 3. Result of analysis of variance ( $F$ values) and mean for morphophysiological characters and mean grain yield of corn crop ( $\mathrm{kg} \mathrm{ha}^{-1}$ ) when testing scarification, sowing system and soil cover in an Oxisol. Guarapuava-PR, 2019.

\begin{tabular}{|c|c|c|c|c|c|c|c|c|c|c|}
\hline VS & Chlorophyll & $\mathbf{P H}$ & EIH & SD & EL & NR & NGR & ED & W1000 & Yield \\
\hline & \multicolumn{10}{|c|}{ F Values } \\
\hline Scarification & $24.94 *$ & 0.00 & 0.12 & 0.11 & 2.47 & 0.09 & 0.33 & 0.68 & $19.05^{*}$ & 0.34 \\
\hline Sowing & 0.48 & $6.35^{+}$ & $17.72 *$ & 2.85 & 2.44 & 1.15 & 6.53 & 1.79 & 0.09 & $10.64^{*}$ \\
\hline Sowing*Scarification & 0.01 & 3.11 & 1.76 & 1.87 & 1.19 & 0.28 & 1.76 & 0.02 & 1.67 & 1.33 \\
\hline Cover & 0.31 & 0.56 & 0.80 & 0.54 & 0.54 & 2.39 & 0.94 & 0.02 & $3.23^{+}$ & $2.84+$ \\
\hline Cover*Scarification & 1.02 & 1.65 & 2.21 & 0.69 & 0.20 & 0.22 & 1.83 & 0.57 & 1.70 & 0.67 \\
\hline Cover*Sowing & 1.27 & 1.52 & 0.31 & 0.43 & $4.09 *$ & 0.71 & $3.97^{*}$ & 0.03 & 0.67 & 2.47 \\
\hline Cover*Sowing*Scarification & 0.07 & 0.20 & 0.05 & 0.41 & 1.61 & 0.24 & 0.76 & 0.76 & 0.24 & 0.71 \\
\hline CV Scarification (\%) & 3.94 & 5.83 & 15.26 & 7.85 & 10.26 & 5.64 & 5.76 & 2.88 & 1.43 & 10.21 \\
\hline CV Sowing (\%) & 5.28 & 4.01 & 5.57 & 7.17 & 9.41 & 9.66 & 8.49 & 3.15 & 4.58 & 8.81 \\
\hline \multirow[t]{3}{*}{ CV Cover (\%) } & 4.24 & 3.45 & 8.38 & 6.08 & 6.99 & 5.78 & 7.52 & 2.79 & 3.78 & 8.45 \\
\hline & \multicolumn{10}{|c|}{ General mean } \\
\hline & 534.67 & $2.19 \mathrm{~m}$ & $1.11 \mathrm{~m}$ & $19.30 \mathrm{~mm}$ & $13.35 \mathrm{~cm}$ & 14.88 & 27.16 & $46.84 \mathrm{~mm}$ & $306.1 \mathrm{~g}$ & $10009.39 \mathrm{~kg} \mathrm{ha}^{-1}$ \\
\hline
\end{tabular}

PH: plant height; EIH: ear insertion height; SD: stem diameter; Chlorophyll: total chlorophyll; EL: ear length; NR: number of rows; NGR: number of grains per rows; ED: ear diameter; W1000: weight of 1000 grains; Yield: corn yield. $(+) 10 \% ;(*) 5 \%$ and $(* *) 1 \%$ of error probability. 


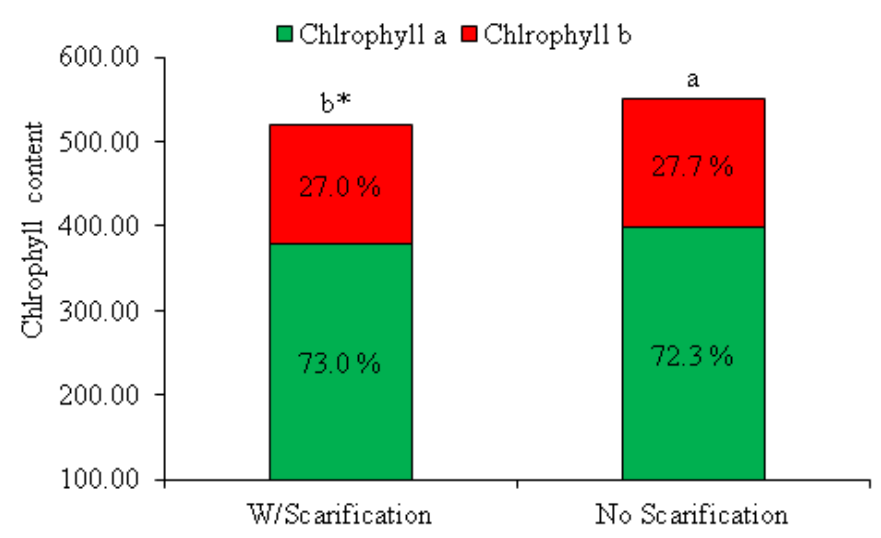

* Means followed by the same letter do not differ from each other by the $\mathrm{F}$ test $(p \geq 0.05)$. Figure 3. Total chlorophyll content and percentage of chlorophyll a and chlorophyll b in corn crop in an environment with and without scarification in an Oxisol. Guarapuava-PR, 2018.

the environment change. Researches studying the relation between the chlorophyll meter reading and the corn crop yield, fertilized with different nitrogen doses, found a positive response of this correlation (França et al., 2011; Segatto et al., 2017). Quaggiotti et al. (2004), while studying the effect of humic substances on nitrate absorption, found that the application of humic acids stimulates nitrate uptake by corn roots, thus explaining the higher total chlorophyll content in areas without scarification. In no-tillage areas, such as the area without scarification, the organic matter, coupled with its humic fractions, is one of the most affected components (Moraes Sá et al., 2015; Gazolla et al., 2015) and are probably positively influencing the chlorophyll content of corn plants by increasing nitrogen uptake in its different forms. Rosa et al. (2017), studying the cover crops effect on their organic fractions, found that those crops increased soil organic matter and carbon content in the fulvic acid fraction, which may respond positively to soil fertility.

As for the characters found at the harvesting time, ear insertion height was higher when sowing was performed with double disc, reaching ear insertion height of 1.15 (Figure 4). In

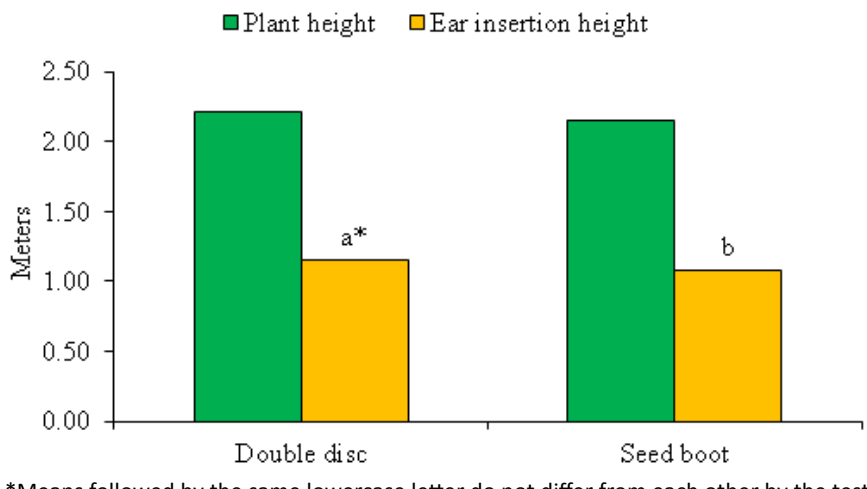

*Means followed by the same lowercase letter do not differ from each other by the test $\mathrm{F}(p \geq 0.05)$

Figure 4. Plant height and insertion height of corn crop ear for double disc and furrow sowing system, independent of scarification and green manure. a study comparing the potential of different corn hybrids in a Dystrophic Haplic Cambisol in Cfa climate region, Kuneski et al. (2017) found that the hybrid P3456 reached ear insertion height of $1.28 \mathrm{~m}$. It is noted that the height of ear insertion for double disc sowing was $0.08 \mathrm{~m}$ higher than the seed boot. A possible reason for this result is the quality of corn sowing, which has a direct impact on crop yield (Silva et al., 2017). The better efficiency of the double disc compared to the seed boot is reported by Santos Junior \& Pasini (2019), especially at higher working speeds. Sowing quality, emergence and germination speed are the most-likely causes of the results found for ear insertion height, affecting the phenotypic expression of the studied hybrid. Different results were found by Giacomeli et al. (2016), who studying the effects of different furrowers in Planosols, found lower double ear corn ear insertion values when compared with the seed boot for two distinct regions when testing the 30F53YR hybrid; however, in this case the soil physical conditions were limiting, and when the seed boot was used, the plants water stress was lower due to the improved macroporosity, reduced penetration resistance and increased root concentration at greater depths.

Ear length and number of grains per row showed interaction for the cover $x$ sowing factors, specifically in the fallow, in which both characters were lower for the areas sowed with seed boot (Figure 5). There is a direct relation between ear length and grain number in the present study, corroborating the data obtained by other authors (Vilela et al., 2012; Araújo et al., 2017). Moreover, Lima et al. (2012b) emphasize that the higher number of grains per row results in higher yield for corn crop. In this study, areas kept in fallow and sowed with seed boot were lower for these attributes, favoring lower productive response.

Regarding the weight of 1000 grains, a mean of $303.3 \mathrm{~g}$ was found for scarified areas and $308.6 \mathrm{~g}$ for non-scarified area (Figure 6). This behavior is consistent with chlorophyll data, and therefore may be associated with soil fertility in the area without scarification. NTS increases the amount of organic matter, the persistence of these residues on the soil

$$
\square \text { Ear length (cm) } \square \text { Number of grains per row }
$$

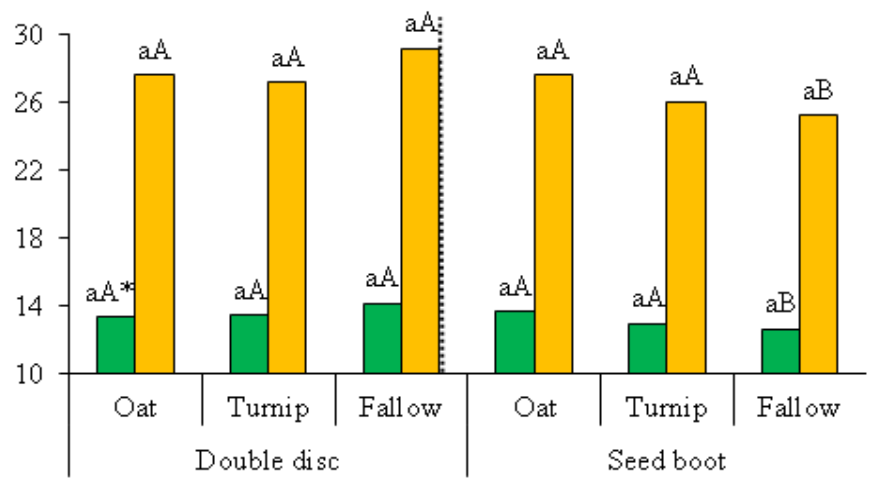

*Means followed by the same lowercase letter do not differ between cover and mean followed by the same uppercase letter do not differ between furrows by the $\mathrm{F}$ test ( $p \geq$ 0.05).

Figure 5. Ear length and number of grains per row of corn sown with different furrowing systems in the seeder and cover of an Oxisol. 


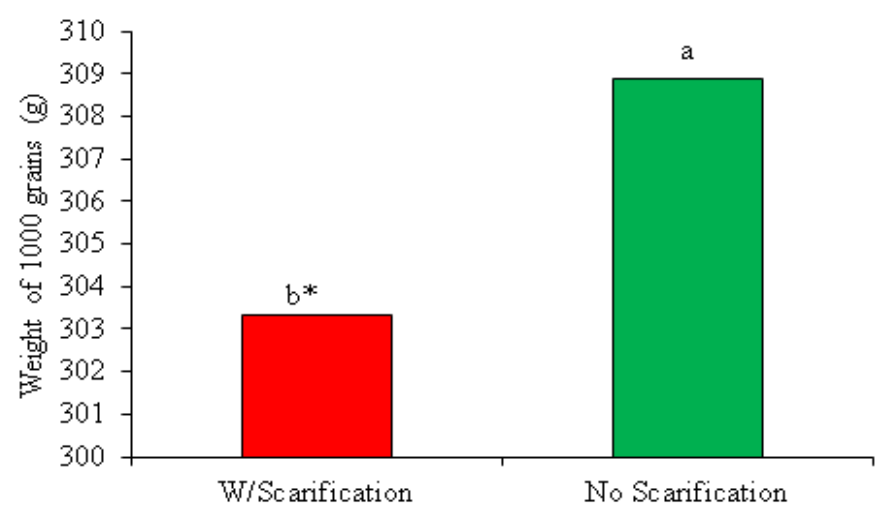

* Means followed by the same lowercase letters do not differ by $\mathrm{F}$ test $(p \geq 0.05)$.

Figure 6. Weight of 1000 corn grains under different management conditions of an Oxisol.

and the nutrients release (Torres \& Pereira, 2008), which may affect the productive traits of corn, such as obtaining a higher grain weight.

Regarding the corn grain yield, there was an effect only for the sowing system. It was found that seed boot system, regardless of the cover type, showed lower mean yield when compared to the double disc (Figure 7). Under conditions with vegetation cover, it was noted an improper functioning of the seed boot, which at various times caused clogging in the machine and may have impaired the proper deposition of seeds and/or fertilizer. Seki et al. (2015), when studying the behavior of different soil unpacking mechanisms, found that both scarification and the use of seed boot in sowing did not interfere with the corn yield. However, Aratani et al. (2006), already in the 2000s, pointed out that the clogging is a problem for many farmers who use furrows in areas with a large amount of straw, since it significantly reduces the operational yield of sowing due to the number of stops needed to unclog it. Coelho (2017), studying the soybean plantability in seeders equipped with different furrowing mechanisms in Haplic Planosol, found that seed boot sowing provided a greater unevenness in seed deposition depth, which may be associated with soil mobilization by this mechanism, which, as verified by Trentin et al. (2018), moves the soil twice more than the double disc system. Seed deposition or even the soil tillage, consequently affecting the moisture, may have affected corn performance under the study conditions. This fact may explain the yield of fallow areas when the seed boot was employed, as since the soil exposure was higher, the greater were the effects of soil moisture oscillation on the development of corn plants.

For the fallow, regardless of the system, the highest found yield variations were with a coefficient of variation close to $10 \%$, while for oat and/or turnip covers it was $6 \%$. This information shows how unstable the fallow areas are in ensuring yield. Soil cover had a significant effect with a $10 \%$ probability of error, so perhaps under adverse conditions management with cover crops has a greater effect on corn yield. Lázaro et al. (2013), studying the effect of corn succession after different green manures in Red Oxisol, emphasized the potential of vegetal cover to improve soil fertility and that they directly affect corn yield.

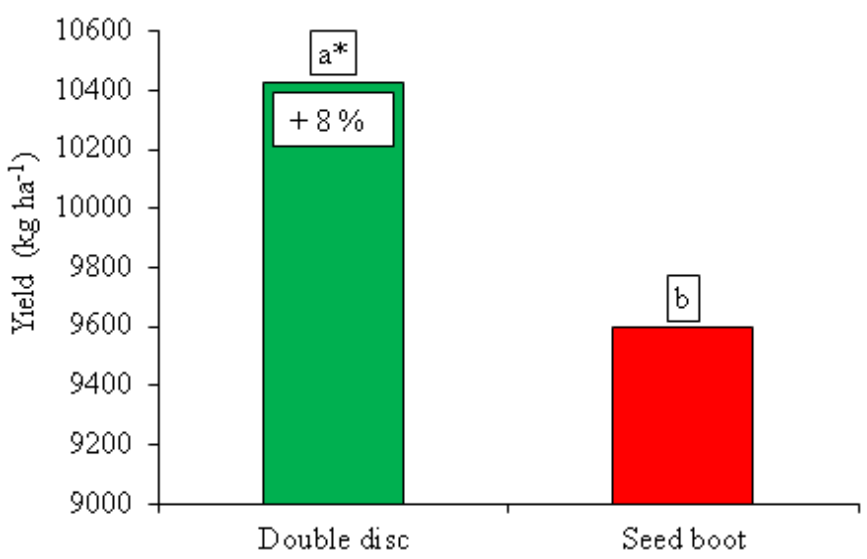

* Means followed by the same lowercase letter do not differ from each other by the $F$ test $(p \geq 0.05)$.

Figure 7. Mean grain yield of corn crop with different systems in the seeder in an Oxisol area. Guarapuava-PR, 2018.

\section{Dry matter yield of soil covers after corn cultivation}

After corn cultivation, new soil covering treatments were implemented: black oat + forage turnip, mulch mix and fallow. In these, it was found that the dry matter production had an effect between the different covers and furrowing mechanisms (Table 4).

Dry matter yield was considerably higher in plots cultivated with the Green Manure Mix and Oat + Turnip when compared to the fallow. Oat + turnip cultivation showed a difference between scarified and non-scarified areas and the covers mix did not differ (Figure 8). Moreover, Oat + Turnip performance is superior when grown in areas managed with double disc furrower mechanism. When using a seed boot, the Mix performance was superior (Figure 9). In any case, in both situations, dry matter production came close to or even exceeded $6,000 \mathrm{~kg} \mathrm{ha}^{-1}$ for cover crops. From a nutrient recycling point of view, cover cropping with green manure mix would be more interesting given that different species have the ability to absorb or fix a particular element (Casali et al., 2011; Calegari et al., 2013; Wolschick et al., 2016). Acknowledge studies demonstrate that green manures such as black oat, forage turnip and vetches accumulate significant amounts of nitrogen and potassium in their dry matter (Borkert et al., 2003; Crusciol et

Table 4. Result of analysis of variance ( $F$ values) and mean dry matter for soil covering after corn crop in an Oxisol. Guarapuava-PR, 2019.

\begin{tabular}{cc}
\hline VS & Dry matter \\
\hline Scarification & F Values \\
\hline Sowing & 0.97 \\
Sowing*Scarification & 0.88 \\
Cover & $6.77^{+}$ \\
Cover*Scarification & $207.57^{* *}$ \\
Cover*Sowing & $5.85^{* *}$ \\
Cover*Sowing*Scarification & $7.23^{* *}$ \\
Cv 1 (\%) & 1.82 \\
Cv 2 (\%) & 28.02 \\
Cv 3 (\%) & 14.27 \\
\hline & 19.62 \\
\hline & General mean \\
\hline
\end{tabular}

$(+) 10 \% ;\left(^{*}\right) 5 \%$ and $\left({ }^{* *}\right) 1 \%$ of error probability. 


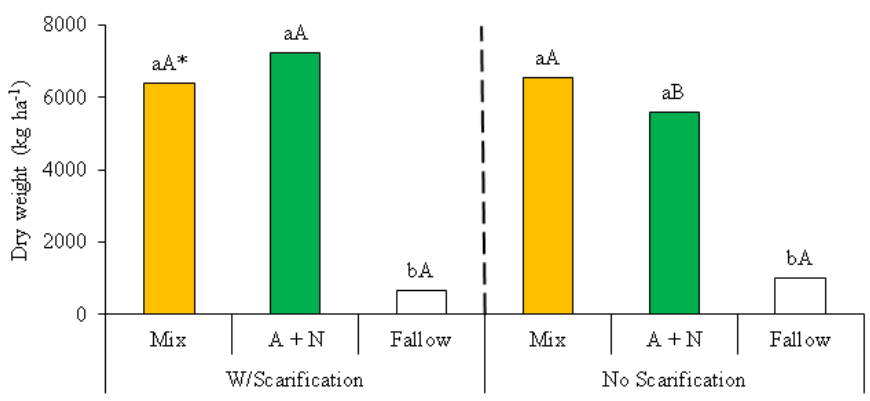

*Means followed by the same lowercase letter do not differ between covers and means followed by the same uppercase letter do not differ between scarification by the $F$ test. $(p \geq 0.05)$.

Figure 8. Dry matter yield of different soil covers after corn cultivation in an Oxisol.

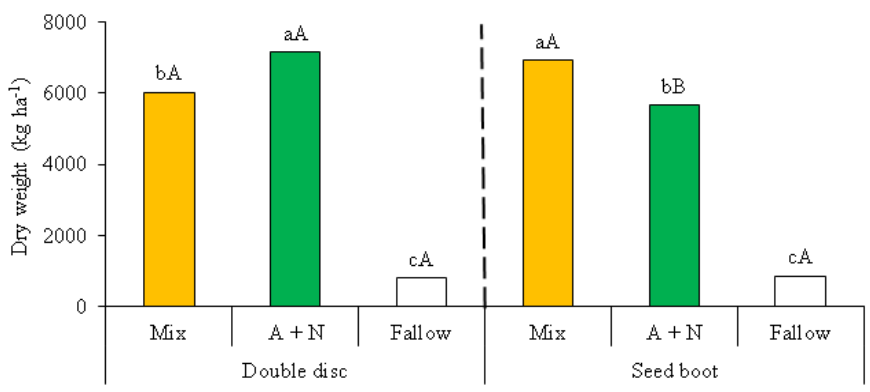

*Means followed by the same lower case letter do not differ covers and means followed by the same upper case letter do not differ Grooving system by Tukey test $(p \geq 0.05)$.

Figure 9. Dry matter yield of different soil covers after corn cultivation in an Oxisol.

al., 2005). In addition to the nutrient recycling aspect, the effect of vegetation cover on weed suppression is also proved. Forte et al. (2018), by studying the effect of different weed management and soil cover systems on Haplic Cambisol, found that plant cover consortia, such as black oat + vetches, are able to significantly suppress weeds by amount of produced dry matter, which among all treatments was the one that obtained the highest mean yield of the three evaluated years. Furthermore, the authors reported that the fallow areas were the ones that had the largest weed infestations, and if also observed in the present study, which although not having evaluated the species, reports weed dry matter production of over $800 \mathrm{~kg} \mathrm{ha}^{-1}$.

\section{Conclusion}

Scarification affected the corn biometric parameters, but not its yield.

Corn yield was higher when sowing was performed with the double disc.

The use of covers benefits corn yield and its production stability.

Soil covering, either with a mix or with black oat + forage turnip shows high potential for dry matter production.

\section{Literature Cited}

Alvares, C.A.; Stape, J.L.; Sentelhas, P.C.; Leonardo, J.; Gonçalves, M.; Sparovek, G. Köppen's climate classification map for Brazil. Meteorologische Zeitschrift, v.22, n.6, p.711-728, 2013. https:// doi.org/10.1127/0941-2948/2013/0507.
Aratani, R.G.; Maria, I.C. de; Castro, O.M. de; Peche Filho, A.; Duarte, A.P.; Kanthack, R.A.D. Desempenho de semeadoras-adubadoras de soja em Latossolo Vermelho muito argiloso com palha intacta de milho. Revista Brasileira de Engenharia Agrícola e Ambiental, v.10, n.2, p.517522, 2006. https://doi.org/10.1590/S1415-43662006000200037.

Araújo, L.D.S.; Silva, L.G.B.; Silveira, P.M. da; Rodrigues, F.; Lima, M.L. DA P.; Cunha, P.C.R. da. Desempenho agronômico de híbridos de milho na região sudeste de Goiás. Revista Agro@mbiente On-Line, v.10, n.4, p.334, 2017. https://doi.org/10.18227/19828470ragro.v10i4.3334.

Borkert, C.M.; Gaudêncio, C. de A.; Pereira, J.E.; Pereira, L.R.; Oliveira Junior, A. de. Nutrientes minerais na biomassa da parte aérea em culturas de cobertura de solo. Pesquisa Agropecuária Brasileira, v.38, n.1, p.143-153, 2003. https://doi.org/10.1590/S0100204X2003000100019.

Botta, G.F.; Tolón-Becerra, A.; Rivero, D.; Laureda, D.; RamírezRoman, M.; Lastra-Bravo, X.; Agnes, D.; Flores-Parra, I.M.; Pelizzari, F.; Martiren, V. Compactión produced by combine harvest traffic: Effect on soil and soybean (Glycine max L.) yields under direct sowing in Argentinean Pampas. European Journal of Agronomy, v.74, p.155-163, 2016. https://doi.org/10.1016/j. eja.2015.12.011.

Brasil. Regras para análise de sementes. 1.ed. Brasília, DF: MAPA, 2009. 399p.

Calegari, A.; Tiecher, T.; Hargrove, W.L.; Ralisch, R.; Tessier, D.; Tourdonnet, S. De; Guimarães, M. De F.; Santos, D.R. Dos. Longterm effect of different soil management systems and winter crops on soil acidity and vertical distribution of nutrients in a Brazilian Oxisol. Soil and Tillage Research, v.133, p.32-39, 2013. https://doi.org/10.1016/j.still.2013.05.009.

Casali, C.A.; Kaminski, J.; Arbugeri, F.E.; Piccin, R.; Doneda, A. Mineralização das formas de fósforo do tecido de plantas de cobertura. Informações Agronômicas, p.21-24, 2011.

Coelho, L.L. Manejo de azevém e de mecanismos sulcadores na implantação e desenvolvimento de soja em terras baixas. Santa Maria: Universidade Federal de Santa Maria, 2017. 78p. Dissertação Mestrado. http://repositorio.ufsm.br/ handle/1/11791. 10 Jan. 2019.

Companhia Nacional de Abastecimento - Conab. Levantamento de safras. http://www.fazenda.gov.br/centrais-de-conteudos/ publicacoes/conjuntura-economica/agricola/2018/ levantamento-de-safras_conab_042018.pdf. 06 Dez. 2018.

Crusciol, C.A.C.; Cottica, R.L.; Lima, E. Do V.; Andreotti, M.; Moro, E.; Marcon, E. Persistência de palhada e liberação de nutrientes do nabo forrageiro no plantio direto. Pesquisa Agropecuária Brasileira, v.40, n.2, p.161-168, 2005. https://doi.org/10.1590/ S0100-204X2005000200009.

Dal Ferro, N.; Sartori, L.; Simonetti, G.; Berti, A.; Morari, F. Soil macroand microstructure as affected by different tillage systems and their effects on maize root growth. Soil and Tillage Research, v.140, p.55-65, 2014. https://doi.org/10.1016/j.still.2014.02.003.

Drescher, M.S.; Eltz, F.L.F.; Denardin, J.E.; Faganello, A.; Drescher, G.L. Resistência à penetração e rendimento da soja após intervenção mecânica em Latossolo Vermelho sob plantio direto. Revista Brasileira de Ciência do Solo, v.36, n.6, p.1836-1844, 2012. https://doi.org/10.1590/S0100-06832012000600018. 
Drescher, M.S.; Reinert, D.J.; Denardin, J.E.; Gubiani, P.I.; Faganello, A.; Silva, B.R. da; Zardin, M.C. Fertilizer shanks to promote soil decompaction in the seeding operation. Ciência Rural, v.47, n.3, e20160026, 2017. https://doi.org/10.1590/01038478 cr20160026.

Empresa Brasileira de Pesquisa Agropecuária - Embrapa. Indicações técnicas para o cultivo de milho e de sorgo no Rio Grande do Sul Safras 2017/2018 e 2018/2019. Sertão, RS: Embrapa, 2017. 209p.

Espessato, R.R.; Leite, F.; Guerreiro, J.C.; Quiqui, E.M. Del; Azevedo, A.P. de; Aleixo, E. V. Soybean development as a function of traffic of tractor with radial tires. Revista Brasileira de Engenharia Agrícola e Ambiental, v.21, n.10, p.726-730, 2017. https://doi. org/10.1590/1807-1929/agriambi.v21n10p726-730.

Fageria, N.K. Mineral nutrition of rice. 1.ed. Boca Raton: Taylor e Francis Group, 2014. 552p.

Federação Brasileira de Plantio Direto na Palha - Febrapd. Área do Sistema Plantio Direto https://febrapdp.org.br/area-de-pd. 04 Dez. 2018.

Forte, C.T.; Beutler, A.N.; Galon, L.; Castoldi, C.T.; Winter, F.L.; Holz, C.M.; Bianchessi, F.; Concenço, G.; Chechi, L.; Ferreira, M.M.; Andres, A.; Burg, G.M. Soil Physical Properties and Grain Yield Influenced by Cover Crops and Crop Rotation. American Journal of Plant Sciences, v.9, n.4, p.584-598, 2018. https://doi. org/10.4236/ajps.2018.94045.

França, S.; Mielniczuk, J.; Rosa, L.M.G.; Bergamaschi, H.; Bergonci, J.I. Nitrogênio disponível ao milho: Crescimento, absorção e rendimento de grãos 1. Revista Brasileira de Engenharia Agrícola e Ambiental, v.15, n.11, p.1143-1151, 2011. https://doi. org/10.1590/S1415-43662011001100006.

Franchini, J.C.; Debiasi, H.; Balbinot JunioR, A.A.; Tonon, B.C.; Farias, J.R.B.; Oliveira, M.C.N. De; Torres, E. Evolution of crop yields in different tillage and cropping systems over two decades in southern Brazil. Field Crops Research, v.137, p.178-185, 2012. https://doi.org/10.1016/j.fcr.2012.09.003.

Gazolla, P.R.; Guareschi, R.F.; Perin, A.; Pereira, M.G.; Rossi, C.Q. Frações da matéria orgânica do solo sob pastagem, sistema plantio direto e integração lavoura-pecuária. Semina: Ciências Agrárias, v.36, n.2, p.693-704, 2015. https://doi.org/10.5433/16790359.2015v36n2p693.

Giacomeli, R.; Marchesan, E.; Sartori, G.M.S.; Donato, G.; Silva, P.R.F. Da; Kaiser, D.R.; Aramburu, B.B. Escarificação do solo e sulcadores em semeadora para cultivo de milho em Planossolos. Pesquisa Agropecuária Brasileira, v.51, n.3, p.261-270, 2016. https://doi. org/10.1590/S0100-204X2016000300008.

Grzesiak, M.T.; Janowiak, F.; Szczyrek, P.; Kaczanowska, K.; Ostrowska, A.; Rut, G.; Hura, T.; Rzepka, A.; Grzesiak, S. Impact of soil compaction stress combined with drought or waterlogging on physiological and biochemical markers in two maize hybrids. Acta Physiologiae Plantarum, v.38, e109, 2016. https://doi. org/10.1007/s11738-016-2128-4.

Guedes Filho, O.; Silva, A.P. da; Giarola, N.F.B.; Tormena, C.A. Permeabilidade ao ar da cama de semeadura do solo em sistema semeadura direta. Revista Brasileira de Ciência do Solo, v.39, n.3, p.841-851, 2015. https://doi.org/10.1590/01000683rb cs20140169.
Kormanek, M.; Głąb, T.; Banach, J.; Szewczyk, G. Effects of soil bulk density on sessile oak Quercus petraea Liebl. seedlings. European Journal of Forest Research, v.134, n.6, p.969-979, 2015. https:// doi.org/10.1007/s10342-015-0902-2.

Krenchinski, F.H.; Cesco, V.J.S.; Rodrigues, D.M.; Albrecht, L.P.; Wobeto, K.S.; Albrecht, A.J.P. Agronomic performance of soybean grown in succession to winter cover crops. Pesquisa Agropecuária Brasileira, v.53, n.8, p.909-917, 2018. https://doi. org/10.1590/S0100-204X2018000800005.

Kuneski, H.F.; Sangoi, L.; Coelho, A.E.; Durli, M.M.; Leolato, L.S.; Voss, R.; Panison, F. Desempenho agronômico de híbridos de milho no Alto Vale do Itajaí - SC. Revista da Jornada de Pós-Graduação e Pesquisa - Congrega URCAMP, v.2017, p.1146-1159, 2017. http://trabalhos.congrega.urcamp.edu.br/index.php/14jpgp/ article/view/2085. 05 Jan. 2019.

Lázaro, R. de L.; Costa, A.C.T. da; Silva, K. de F. da; Sarto, M.V.M.; Duarte Júnior, J.B. Produtividade de milho cultivado em sucessão à adubação verde. Pesquisa Agropecuária Tropical, v.43, n.1, p.1017, 2013. https://doi.org/10.1590/S1983-40632013000100008.

Lima, C.F. de; Arnhold, E.; Araujo, B.L. De; Oliveira, G.H.F. D.; Oliveira Junior, E.A. de. Avaliação de híbridos de milho sob três densidades populacionais em fronteira agrícola no Maranhão. Comunicata Scientiae, v.3, n.1, p.30-34, 2012b. https://doi.org/10.14295/ cs.v3i1.43.

Lima, G.P. de; Nóbrega, L.H.P.; Mauli, M.M.; Rosa, D.M.; Smanhotto, A. Soybean growth and yield after single tillage and species mixture of cover plants. Revista Ceres, v.59, n.5, p.695-700, 2012a. https://doi.org/10.1590/S0034-737X2012000500016.

Mcphee, J.E.; Aird, P.L.; Hardie, M.A.; Corkrey, S.R. The effect of controlled traffic on soil physical properties and tillage requirements for vegetable production. Soil and Tillage Research, v.149, p.33-45, 2015. https://doi.org/10.1016/J. STILL.2014.12.018.

Moraes Sá, J.C. de; Séguy, L.; Tivet, F.; Lal, R.; Bouzinac, S.; Borszowskei, P.R.; Briedis, C.; Santos, J.B. dos; Cruz Hartman, D. da; Bertoloni, C.G.; Rosa, J.; Friedrich, T. Carbon depletion by plowing and its restoration by no-till cropping systems in Oxisols of Subtropical and Tropical Agro-Ecoregions in Brazil. Land Degradation \& Development, v.26, n.6, p.531-543, 2015. https:// doi.org/10.1002/ldr.2218.

Moraes, M.T.; Debiasi, H.; Carlesso, R.; Cezar Franchini, J.; Rodrigues da Silva, V.; Bonini Da Luz, F. Soil physical quality on tillage and cropping systems after two decades in the subtropical region of Brazil. Soil and Tillage Research, v.155, p.351-362, 2016. https:// doi.org/10.1016/J.STILL.2015.07.015.

Nascente, A.S.; Chrisley Lacerda, M.; Cristina Lanna, A.; De Filippi, M.C.C.; Medrado Silva, D. Cover crops can affect soil attributes and yield of upland rice. Australian Journal Crop Science, v.10, n.2, p.176-184, 2016. https://www.cropj.com/ nascente_10_2_2016_176_184.pdf. 11 Jan. 2019.

Oliveira, P.R. de; Centurion, J.F.; Centurion, M.A.P. da C.; Franco, H.B.J.; Pereira, F. de S.; Bárbaro Júnior, L.S.; Rossetti, K. de V. Qualidade física de um Latossolo Vermelho cultivado com soja submetido a níveis de compactação e de irrigação. Revista Brasileira de Ciência do Solo, v.36, n.2, p.587-597, 2012. https:// doi.org/10.1590/S0100-06832012000200028. 
Prado, E.A.F.; Garbiate, M. V; T Vitorino, A.C.; Bergamin, A.C.; Ensinas, S.C. Effect of scarification of a haplustox in post harvest cane sugar. Revista de Ciências Agrárias, v.37, n.4, p.414-421, 2014. http:// www.scielo.mec.pt/scielo.php?script=sci_arttext\&pid=S0871018X2014000400006\&lng=en\&nrm=i\&tlng=pt. 07 Jan. 2019.

Quaggiotti, S.; Ruperti, B.; Pizzeghello, D.; Francioso, O.; Tugnoli, V.; Nardi, S. Effect of low molecular size humic substances on nitrate uptake and expression of genes involved in nitrate transport in maize (Zea mays L.). Journal of Experimental Botany, v.55, n.398, p.803-813, 2004. https://doi.org/10.1093/jxb/erh085.

Reichert, J.M.; Suzuki, L.E.A.S.; Reinert, D.J.; Horn, R.; Håkansson, I. Reference bulk density and critical degree-of-compactness for no-till crop production in subtropical highly weathered soils. Soil and Tillage Research, v.102, n.2, p.242-254, 2009. https://doi. org/10.1016/J.STILL.2008.07.002.

Rosa, D.M.; Nóbrega, L.H.P.; Mauli, M.M.; Lima, G.P. de; Pacheco, F.P. Substâncias húmicas do solo cultivado com plantas de cobertura em rotação com milho e soja. Revista Ciência Agronômica, v.48, n.2, p.221-230, 2017. https://doi.org/10.5935/1806-6690.20170026.

Santos Junior, A.C.M.; Pasini, M.P.B. Eficiência de diferentes sistemas de distribuição de sementes de milho (Zea mays) sob variação de velocidade e haste-sulcadora. Ciência \& Tecnologia, v.3, n.1, p.2-7, 2019. http://revistaeletronica.unicruz.edu.br/index.php/ CIENCIAETECNOLOGIA/article/view/8414/2132. 10 Jan. 2019.

Santos, D. dos; Souza, E.G. de; Nóbrega, L.H.P.; Bazzi, C.L.; Queiroz, F.N. de. Physical properties of soils and soybean yields after planting cover crops. Engenharia Agricola, v.35, n.2, p.280-292, 2015. https:// doi.org/10.1590/1809-4430-Eng.Agric.v35n2p280-292/2015.

Santos, H. dos; Jacomine, P.; Anjos, L. dos; Oliveira, V. de; Lumbreras, J.F.; Coelho, M.; Almeida, J. de; Araujo Filho, J. de; Oliveira, J. de; Cunha, T.J.F. Sistema brasileiro de classificação de solos. 5.ed. Brasília: Embrapa, 2018. 356p. http://www.infoteca.cnptia. embrapa.br/infoteca/handle/doc/1094003. 15 Dez. 2018.

Segatto, C.; Conte, R.; Lajús, C.R.; Luz, G.L. DA. Relação da leitura do clorofilômetro com o rendimento da cultura do milho em diferentes níveis de suprimento de nitrogênio. Scientia Agraria Paranaensis, v.16, n.1, p.253-259, 2017. https://doi. org/10.18188/1983-1471/sap.v16n1p253-259.

Seki, A.S.; Seki, F.G.; Jasper, S.P.; Silva, P.R.A.; Benez, S.H. Effects of soil decompaction techniques in an area under a system of direct seeding. Revista Ciência Agronômica, v.46, n.3, p.460-468, 2015. https://doi.org/10.5935/1806-6690.20150027.
Silva, A.F. da; Resende, Á.V.; Gontijo Neto, M.M.; Borghi, E.; Mattos, E.; Pitta, R.M.; Ferreira, A.; Behling, M. Nota técnica sobre circuito tecnológico milho 2017. Cuiabá: Aprosoja, 2017. 9p. http://ainfo. cnptia.embrapa.br/digital/bitstream/item/164585/1/CircuitoTecnologico-Milho-2017.pdf. 10 Jan. 2019.

Silva, É.A. da; Reinert, D.J.; Reichert, J.M.; Mallmann, M.S.; Pereira, M.A.; Pons, S.S.; Foggiato, W.S. Soil conservation management with cover crops: effects on critical energy levels, release and dispersion of aggregates. Bragantia, Ahead of print, 2019. https:// doi.org/10.1590/1678-4499.20180323.

Torres, J.L.R.; Pereira, M.G. Dinâmica do potássio nos resíduos vegetais de plantas de cobertura no Cerrado. Revista Brasileira de Ciência do Solo, v.32, n.4, p.1609-1618, 2008. https://doi. org/10.1590/S0100-06832008000400025.

Trentin, R.G.; Modolo, A.J.; Vargas, T.D.O.; Campos, J.R. DA R.; Adami, P.F.; Baesso, M.M. Soybean productivity in Rhodic Hapludox compacted by the action of furrow openers. Acta Scientiarum. Agronomy, v.40, n.1, p.35015, 2018. https://doi.org/10.4025/ actasciagron.v40i1.35015.

Valicheski, R.R.; Grossklaus, F.; Stürmer, S.L.K.; Tramontin, A.L.; BaadE, E.S.A.S. Desenvolvimento de plantas de cobertura e produtividade da soja conforme atributos físicos em solo compactado. Revista Brasileira de Engenharia Agrícola e Ambiental, v.16, n.9, p.969-977, 2012. https://doi.org/10.1590/ S1415-43662012000900007.

Vilela, R.G.; ARF, O.; Kappes, C.; Kaneko, F.H.; Gitti, D. De C.; Ferreira, J.P. Desempenho agronômico de híbridos de milho, em função da aplicação foliar de fungicidas. Bioscience Journal, v.28, n.1, p.2533, 2012. http://www.seer.ufu.br/index.php/biosciencejournal/ article/view/11672. 02 Fev. 2019.

Wolschick, N.H.; Barbosa, F.T.; Bertol, I.; Santos, K.F. dos; Werner, R. de S.; Bagio, B. Cobertura do solo, produção de biomassa e acúmulo de nutrientes por plantas de cobertura. Revista de Ciências Agroveterinárias, v.15, n.2, p.134-143, 2016. https:// doi.org/10.5965/223811711522016134.

Ziech, A.R.D.; Conceição, P.C.; Luchese, A.V.; Balin, N.M.; Candiotto, G.; Garmus, T.G. Proteção do solo por plantas de cobertura de ciclo hibernal na região Sul do Brasil. Pesquisa Agropecuária Brasileira, v.50, n.5, p.374-382, 2015. https://doi.org/10.1590/ S0100-204X2015000500004. 